\title{
Alcohol consumption and burden of disease in the Americas: implications for alcohol policy
}

\author{
Jürgen Rehm ${ }^{1}$ and Maristela Monteiro ${ }^{2}$
}

Suggested citation

Rehm J, Monteiro M. Alcohol consumption and burden of disease in the Americas: implications for alcohol policy. Rev Panam Salud Publica. 2005;18(4/5):241-8.

ABSTRACT Objectives. To describe patterns of alcohol consumption in the Americas, to estimate the burden of disease attributable to alcohol in the year 2000, and to suggest implications for policies to reduce alcohol-related disease burden.

Methods. Two dimensions of alcohol exposure were included in this secondary data analysis: average volume of alcohol consumption and patterns of drinking. There were two main outcome measures: mortality (number of deaths) and disability-adjusted life years (DALYs) lost (number of years of life lost due to premature mortality and disability). Separate estimates were obtained for different sexes, age groups and WHO regions.

Results. Despite regional variations, alcohol consumption in the Americas averaged more than $50 \%$ higher than worldwide consumption. Patterns of irregular heavy drinking prevailed. Alcohol consumption caused a considerable disease burden: $4.8 \%$ of all the deaths and $9.7 \%$ of all DALYs lost in the year 2000 were attributable to drinking, with most of the burden occurring outside North America. Intentional and unintentional injuries accounted for $59.8 \%$ of all alcohol-related deaths and $38.4 \%$ of the alcohol-related disease burden. Of all risk factors compared here, alcohol accounted for the greatest proportion of risk, followed by smoking.

Conclusions. Interventions should be implemented to reduce the high burden of alcoholrelated disease in the Americas. Given the epidemiological structure of this burden, injury prevention including, but not restricted to, prevention of traffic injuries, as well as appropriate treatment options, should play an important role in comprehensive plans to reduce the alcoholrelated public health burden.

Key words Alcohol; risk factor; burden of disease; mortality; disability adjusted life years; America.

Alcohol is one of the major risk factors for burden of disease and social

\footnotetext{
1 Centre for Addiction and Mental Health, Toronto, Canada. Send correspondence and reprint requests to Jürgen Rehm, Ph.D., Senior Scientist and Co-Head, Section of Public Health and Regulatory Policies, Centre for Addiction and Mental Health, 33 Russell Street, Room 2035, Toronto, Ontario, Canada M5S 2S1; telephone: (1) 4165358501 ext. 6907; fax: (1) 416260 4156; e-mail: jtrehm@aol.com

2 Pan American Health Organization (PAHO), Washington, D.C., United States of America.
}

harm in both developing and developed countries (1-4). The objectives of this paper are to report the amount of alcohol consumption in the Americas, to estimate the disease burden attributable to alcohol for different regions of the Americas, and to suggest implications for public health policies. Our findings are based on the results of the Comparative Risk Analysis (CRA), which was part of the World Health Organization (WHO) Global Burden of Disease (GBD) 2000 study (for results for the CRA see references 1-3; for a more general description of the GBD study see references 5 and 6). Because the CRA was restricted to disease burden, the estimates reported here excluded social harm other than the unintentional and intentional injury cate- 
gories included in the International Classification of Disease (for an overview of ICD categories to which alcohol is causally related see reference 7).

Two dimensions of alcohol were considered: average volume of alcohol consumption and patterns of drinking. The latter was recorded mainly as the number of heavy drinking bouts and episodes of intoxication $(3,8)$. Both dimensions were estimated on the country level and then aggregated into WHO regions (9). The burdens of various disease outcomes were estimated at the regional level based on epidemiological research on risk relations between average volumes of alcohol consumption, drinking patterns, and different disease and injury categories (7).

\section{METHODS}

\section{Exposure estimates}

The regional subgroupings for the Americas defined by WHO (9) on the basis of adult and of infant mortality are shown in Table 1.

The exact procedures used to estimate global exposure to alcohol are described in detail elsewhere $(3,8)$. As mentioned, two dimensions of alcohol consumption relevant for disease burden were used in this secondary analysis: average volume of alcohol consumption and a summary score for drinking patterns.

The prevalence of different average volumes of intake in each country was estimated for men and women and for four age categories. The categories of drinking were abstainer, category I (women $>0$ to $<20 \mathrm{~g}$, men $>0$ to $<40 \mathrm{~g}$ ), category II (women 20 to $<40 \mathrm{~g}$, men 40 to $<60 \mathrm{~g}$ ), and category III (women $>40 \mathrm{~g}$; men $>60 \mathrm{~g}$ ) (10). The prevalence of each category in each country was estimated with triangulation from data for adult per capita consumption, and, when available, general population survey results $(8,11)$ obtained mostly from the WHO Global Alcohol Database (12).

A score reflecting the riskiness of cultural drinking patterns was calculated for countries on the basis of in-

TABLE 1. Classification of countries in the Americas according to childhood and adult mortality

\begin{tabular}{lll}
\hline \multicolumn{1}{c}{ Region A } \\
$\begin{array}{c}\text { Very low childhood and } \\
\text { very low adult mortality }\end{array}$ & \multicolumn{1}{c}{$\begin{array}{c}\text { Region B } \\
\text { Low childhood and } \\
\text { low adult mortality }\end{array}$} & $\begin{array}{c}\text { Region D } \\
\text { High childhood and } \\
\text { high adult mortality }\end{array}$ \\
\hline $\begin{array}{l}\text { Canada, Cuba, United States } \\
\text { of America }\end{array}$ & $\begin{array}{l}\text { Antigua and Barbuda, Argentina, } \\
\text { Bahamas, Barbados, Belize, } \\
\text { Brazil, Chile, Colombia, Costa } \\
\text { Rica, Dominica, Dominican }\end{array}$ & $\begin{array}{l}\text { Bolivia, Ecuador, Guatemala, } \\
\text { Haiti, Nicaragua, Peru }\end{array}$ \\
& Republic, El Salvador, Grenada, & \\
& Guyana, Honduras, Jamaica, & \\
& Mexico, Panama, Paraguay, & \\
& Saint Kitts and Nevis, Saint & \\
& Lucia, Saint Vincent and the & \\
& Grenadines, Suriname, Trinidad & \\
& and Tobago, Uruguay, Venezuela & \\
\end{tabular}

a Regional subgroups defined by the World Health Organization (9) on the basis of high, medium or low levels of adult and of infant mortality.

formation from general population surveys relating to alcohol consumption in heavy drinking bouts, outside of meal times, and in public places (8, 11). This score was ordinal and ranged from 1 to 4 , with 1 (assuming all other factors are constant) representing the lowest risk of mortality and burden of disease, and 4 representing the highest risk (3). In other words, the score for patterns of drinking reflected the risk for mortality and burden of disease associated with different volumes of alcohol intake. The higher the score, the higher the associated mortality and burden of disease (3).

Surveys on drinking patterns were scarcer, thus the information used to calculate the score for drinking patterns was sufficient for only 7 countries. For another 20 countries the pattern score was estimated by key informants based on social and cultural factors (e.g., type of drinking culture, religion, etc.), on drinking patterns in neighboring countries or on small regional studies (3).

Uncertainty of the estimates for each dimension was also quantified (3) in accordance with the approach used in the Global Burden of Disease 2000 study (2).

\section{Outcome categories}

Outcome categories in the CRA were defined to be consistent across several risk factors (2) and to correspond with the categories used for the GBD 2000 study $(6,11,13)$. The GBD 2000 categories of disease used were broader than the ICD codes.

\section{Risk relations}

Details of the procedures employed to quantify the risk of disease attributable to alcohol use are described elsewhere $(3,7)$. In general, for most chronic disease categories, alcoholattributable fractions (AAFs) of disease were derived from combining prevalence and relative risk estimates based on metaanalyses (3, 10, 14-16). For depression, AAFs were derived from mental health surveys, taking into consideration the rates of comorbidity, time of onset for alcohol use disorders and depression compared to other mental diseases comorbid with alcohol (3). For coronary heart disease the interaction of average volume and patterns of drinking was modeled using multilevel analyses (see reference 17 for methods, and references 3 and 18 for results). For the final estimates relating to coronary heart disease, AAFs were based on these multilevel results for all countries except those in American region $\mathrm{A}$, where data for drinking patterns were based on a metaanalysis $(3,15)$. For injuries, the same method was used to quantify 
the interaction between average volume of consumption and patterns of drinking to determine AAFs $(3,17)$.

\section{RESULTS}

Country-level indicators of alcohol exposure and economic development are summarized in Table 2. Per capita consumption including unrecorded consumption varied almost seven-fold in American countries, from 2.4 liters of pure alcohol (Trinidad and Tobago) to 16.3 liters (Argentina). The population-weighted average value in the Americas was 8.9 liters, well above the global average per capita consumption of 5.8 liters (Table 3 ). Overall, there was a tendency for higher levels of economic development (as measured in per capita gross domestic product) to be associated with higher levels of alcohol consumption (Pearson's $r=0.34, P=0.086 ; n=27)$. On average (for all countries) about $22 \%$ of the per capita consumption was unrecorded. Unrecorded consumption varied from -0.5 liters for Barbados (subtraction of estimated consumption by tourists accounts for the negative number) to 4.0 liters in Mexico.

All countries showed substantial consumption in the form of irregular heavy drinking bouts. No country in the Americas had a drinking pattern score of 1, a score found only in Europe and Japan (3). A drinking pattern score of 1 , characterized by regular drinking most often with meals and without irregular heavy drinking bouts, has been related to a relatively lower burden of mortality and disease than other drinking styles. Countries in North America and the Caribbean, along with Argentina, had a drinking pattern score of 2, whereas drinking pattern 4 (the highest level of irregular heavy drinking) was most frequent in Central American countries. Given the properties of the drinking pattern score, this means that in Central America the same volume of drinking was related with a greater burden of disease and mortality than in other American countries. Almost twice as many women $(43 \%$ of all adult women) as men (24\%) were abstinent.

Table 3 gives an overview of alcohol consumption by region, and compares these figures with global estimates. Region A, which includes Cuba, the United States and Canada, had the

TABLE 2. Alcohol exposure and economic characteristics of countries in the Americas, 2000 (from reference 3)

\begin{tabular}{|c|c|c|c|c|c|c|c|c|c|}
\hline \multirow{2}{*}{$\begin{array}{c}\text { Country } \\
\text { (WHO } \\
\text { classification) }\end{array}$} & \multirow{2}{*}{$\begin{array}{c}\text { Per } \\
\text { capita } \\
\text { consumption }\end{array}$} & \multirow{2}{*}{$\begin{array}{l}\text { Unrecorded } \\
\text { consumption }\end{array}$} & \multirow{2}{*}{$\begin{array}{l}\text { Drinking } \\
\text { patterns }^{c}\end{array}$} & \multicolumn{2}{|c|}{ Abstainers (\%) } & \multirow{2}{*}{$\begin{array}{c}\text { Per } \\
\text { capita } \\
\text { consumption } \\
\text { per drinkerd }^{\text {d }}\end{array}$} & \multirow{2}{*}{$\begin{array}{c}\text { Per } \\
\text { capita } \\
\text { GDP } \\
\text { US\$e }\end{array}$} & \multirow{2}{*}{$\begin{array}{l}\text { PPP per } \\
\text { capita } \\
\text { GDP } \mid \$^{f}\end{array}$} & \multirow{2}{*}{$\begin{array}{c}\text { Population } \\
15 \text { years } \\
\text { and older } \\
\text { (thousands) }\end{array}$} \\
\hline & & & & Males & Females & & & & \\
\hline Argentina (B) & 16.3 & 1.0 & 2 & 7 & 21 & 19.0 & 7460 & 10980 & 26767 \\
\hline Barbados (B) & 7.4 & -0.5 & 2 & 29 & 70 & 14.8 & 9250 & 15110 & 214 \\
\hline Belize (B) & 6.4 & 2.0 & 4 & 24 & 44 & 9.7 & 3110 & 5150 & 145 \\
\hline Bolivia (D) & 5.7 & 3.0 & 3 & 24 & 45 & 8.7 & 990 & 2240 & 5029 \\
\hline Brazil (B) & 8.6 & 3.0 & 3 & 13 & 31 & 11.1 & 3580 & 7070 & 121039 \\
\hline Canada (A) & 9.4 & 1.0 & 2 & 17 & 28 & 12.1 & 21130 & 26530 & 25248 \\
\hline Chile (B) & 8.3 & 1.0 & 3 & 31 & 47 & 13.6 & 4590 & 8840 & 10883 \\
\hline Colombia (B) & 8.3 & 2.0 & 3 & 31 & 47 & 13.6 & 2020 & 6790 & 28471 \\
\hline Costa Rica (B) & 6.7 & 2.0 & 3 & 45 & 70 & 15.9 & 3810 & 9260 & 2721 \\
\hline Cuba $(A)$ & 5.7 & 2.0 & 2 & 29 & 70 & 11.4 & 2995 & - & 8823 \\
\hline Dominican Republic (B) & 5.7 & 1.0 & 2 & 12 & 35 & 7.5 & 2130 & 6650 & 5688 \\
\hline Ecuador (D) & 5.5 & 3.7 & 3 & 41 & 67 & 12.0 & 1210 & 2960 & 8368 \\
\hline El Salvador (B) & 4.6 & 2.0 & 4 & 9 & 38 & 6.0 & 2000 & 5160 & 4042 \\
\hline Guatemala (D) & 3.7 & 2.0 & 4 & 49 & 84 & 11.2 & 1680 & 4380 & 6420 \\
\hline Guyana (B) & 12.1 & 2.0 & 3 & 20 & 40 & 17.3 & 860 & 4280 & 604 \\
\hline Haiti (D) & 5.4 & 0.0 & 2 & 58 & 62 & 13.5 & 510 & 1870 & 4875 \\
\hline Honduras (B) & 4.2 & 2.0 & 4 & 9 & 38 & 5.5 & 860 & 2760 & 3784 \\
\hline Jamaica (B) & 4.3 & 1.0 & 2 & 29 & 70 & 8.6 & 2610 & 3490 & 1781 \\
\hline Mexico (B) & 8.2 & 4.0 & 4 & 36 & 65 & 16.7 & 5070 & 8240 & 66105 \\
\hline Nicaragua (D) & 3.7 & 1.0 & 4 & 9 & 38 & 4.9 & 400 & - & 2905 \\
\hline Paraguay (B) & 9.6 & 1.5 & 3 & 9 & 33 & 12.2 & 1440 & 5180 & 3324 \\
\hline Peru (D) & 5.4 & 1.0 & 3 & 17 & 24 & 6.8 & 2080 & 4470 & 17094 \\
\hline Suriname $(B)$ & 6.0 & 0.0 & 3 & 30 & 55 & 10.5 & 1890 & - & 290 \\
\hline Trinidad and Tobago (B) & 2.4 & 0.0 & 2 & 29 & 70 & 4.8 & 4930 & 8620 & 971 \\
\hline United States $(\mathrm{A})$ & 9.5 & 1.0 & 2 & 28 & 43 & 14.8 & 34280 & 34280 & 218586 \\
\hline Uruguay (B) & 9.5 & 2.0 & 3 & 25 & 43 & 14.4 & 6000 & 8250 & 2510 \\
\hline Venezuela (B) & 9.6 & 2.0 & 3 & 30 & 55 & 16.8 & 4310 & 5590 & 15943 \\
\hline
\end{tabular}


TABLE 3. Characteristics of adult alcohol consumption in different regions of the Americas, 2000 (population-weighted averages across countries, based on Table 2)

\begin{tabular}{|c|c|c|c|c|c|c|c|c|}
\hline WHO Region & $\begin{array}{l}\text { Beverage } \\
\text { type } \\
\text { most } \\
\text { consumed }\end{array}$ & $\begin{array}{c}\text { Total } \\
\text { consumption } \\
\text { (liters) }^{\mathrm{a}}\end{array}$ & $\begin{array}{c}\text { Unrecorded } \\
\text { consumption }^{b} \\
\%\end{array}$ & $\begin{array}{c}\text { Heavy } \\
\text { drinkers }^{\mathrm{c}} \\
\%\end{array}$ & $\begin{array}{c}\text { Drinkers } \\
\text { among } \\
\text { males } \\
\%\end{array}$ & $\begin{array}{c}\text { Drinkers } \\
\text { among } \\
\text { females } \\
\%\end{array}$ & $\begin{array}{c}\text { Consumption } \\
\text { per } \\
\text { drinker }\end{array}$ & $\begin{array}{l}\text { Average } \\
\text { drinking } \\
\text { patterne }\end{array}$ \\
\hline $\begin{array}{l}\text { Region A } \\
\text { (Canada, Cuba, } \\
\text { United States) }\end{array}$ & $\begin{array}{l}>50 \% \text { beer, } \\
\text { about } 25 \% \\
\text { spirits }\end{array}$ & 9.3 & 11 & 11.2 & 73 & 58 & 14.3 & 2.0 \\
\hline $\begin{array}{l}\text { Region B } \\
\text { (e.g. Brazil, Mexico; } \\
\text { see Table 1) }\end{array}$ & $\begin{array}{l}\text { Beer, } \\
\text { followed } \\
\text { by spirits }\end{array}$ & 9.0 & 30 & 9.1 & 75 & 53 & 14.1 & 3.1 \\
\hline $\begin{array}{l}\text { Region D } \\
\text { (e.g. Bolivia, Peru; } \\
\text { see Table 1) }\end{array}$ & $\begin{array}{l}\text { Spirits, } \\
\text { followed } \\
\text { by beer }\end{array}$ & 5.1 & 34 & 2.7 & 74 & 60 & 7.6 & 3.1 \\
\hline World & Spirits & 5.8 & 40 & 5.1 & 60 & 32 & 12.3 & 2.5 \\
\hline
\end{tabular}

a Estimated total alcohol consumption per resident aged 15 years and older in liters of absolute alcohol (recorded and unrecorded).

${ }^{\mathrm{b}}$ Percentage of total adult per capita consumption (= column 3 ) estimated to be unrecorded.

${ }^{c}$ Estimated \% rate of heavy drinking (males $\geq 40 \mathrm{~g}$, females $\geq 20 \mathrm{~g}$ ) among those aged 15 years or more.

${ }^{\mathrm{d}}$ Estimated total alcohol consumption (liters of absolute alcohol) per adult drinker aged 15 years or more.

${ }^{e}$ Estimated average pattern of drinking (1-4 with 4 indicating most detrimental).

highest overall volume of consumption, the lowest percentage of unrecorded consumption, and the average drinking pattern with potentially the least detrimental impact on public health. Region B had about the same level of consumption as region $\mathrm{A}$, but had more unrecorded consumption and a drinking pattern with a potentially greater detrimental impact on public health. Region D, the region with the highest overall mortality and the lowest level of economic development, had a lower level of alcohol consumption overall, but high levels of unrecorded consumption and about the same drinking pattern as region $B$. All three regions had a similar level of abstention, which was lower than the global level (not shown).

Alcohol consumption caused considerable disease burden: $4.8 \%$ of all the deaths (Table 4) and $9.7 \%$ of all disability-adjusted life years (DALYs) lost in the year 2000 (Table 5) were attributable to this exposure, with most of the burden in the Americas occurring outside North America. Again, these numbers were considerably higher than the global figures of $3.2 \%$ of all deaths (Table 4 ) and $4.0 \%$ of all
DALYs lost (Table 5). Of all regions in the Americas, the burden was relatively highest for men in Region B, where $14.2 \%$ of all deaths and $17.3 \%$ of all the disease burden was attributable to alcohol consumption.

In all regions mortality and disease burden were higher for men than for women. Injury was the category which accounted for most deaths (59.8\%) (Table 4, unintentional + intentional injury) and a considerable burden of disease $(38.4 \%)$ (Table 5). The latter figure, however, was surpassed by neuropsychiatric disorders $(50.1 \%)$ (Table 5), a category almost entirely made up of alcohol-use disorders. The difference between deaths and DALYs lost was due to the fact that alcohol use disorders cause high rates of disability but are not necessarily lethal. The high level of alcohol-use disorders in the Americas was recently confirmed by the World Mental Health survey (19), where three sites in the Americas (United States, Colombia and Mexico) showed consistently higher rates of alcohol-use disorders than the average for any other continents including Europe. (See references 20-22 for further evidence of the high level of alcohol-use disorders in these countries, and in Brazil, Canada and Chile).

Regarding the relationship between vascular diseases and alcohol use, an overall protective effect was predicted for region $\mathrm{A}$, the region with the least detrimental drinking pattern. Relatively regular drinking without many heavy drinking bouts has been linked to protective effects on ischemic diseases $(23,24)$, and evidence of a protective effect of this pattern of alcohol use has been found in North American cohorts (see the literature cited in reference 15; for evidence from cohorts with a more irregular pattern of heavy drinking, see reference 25). Elsewhere in the Americas the overall impact of alcohol consumption was estimated to cause a substantial amount of vascular disease, as predicted by the different biochemical processes related to irregular heavy drinking $(23,26)$. Recent epidemiological research has confirmed these estimates (27).

Table 6 summarizes the distribution of the burden of alcohol-related disease in different age groups in the Americas. Alcohol-related diseases and injuries were found to occur relatively early in life, with most of the al- 
TABLE 4. Alcohol-attributable deaths (thousands) in $\mathbf{2 0 0 0}$ in the Americas and in the world by disease category and region (calculated from data in reference 2)

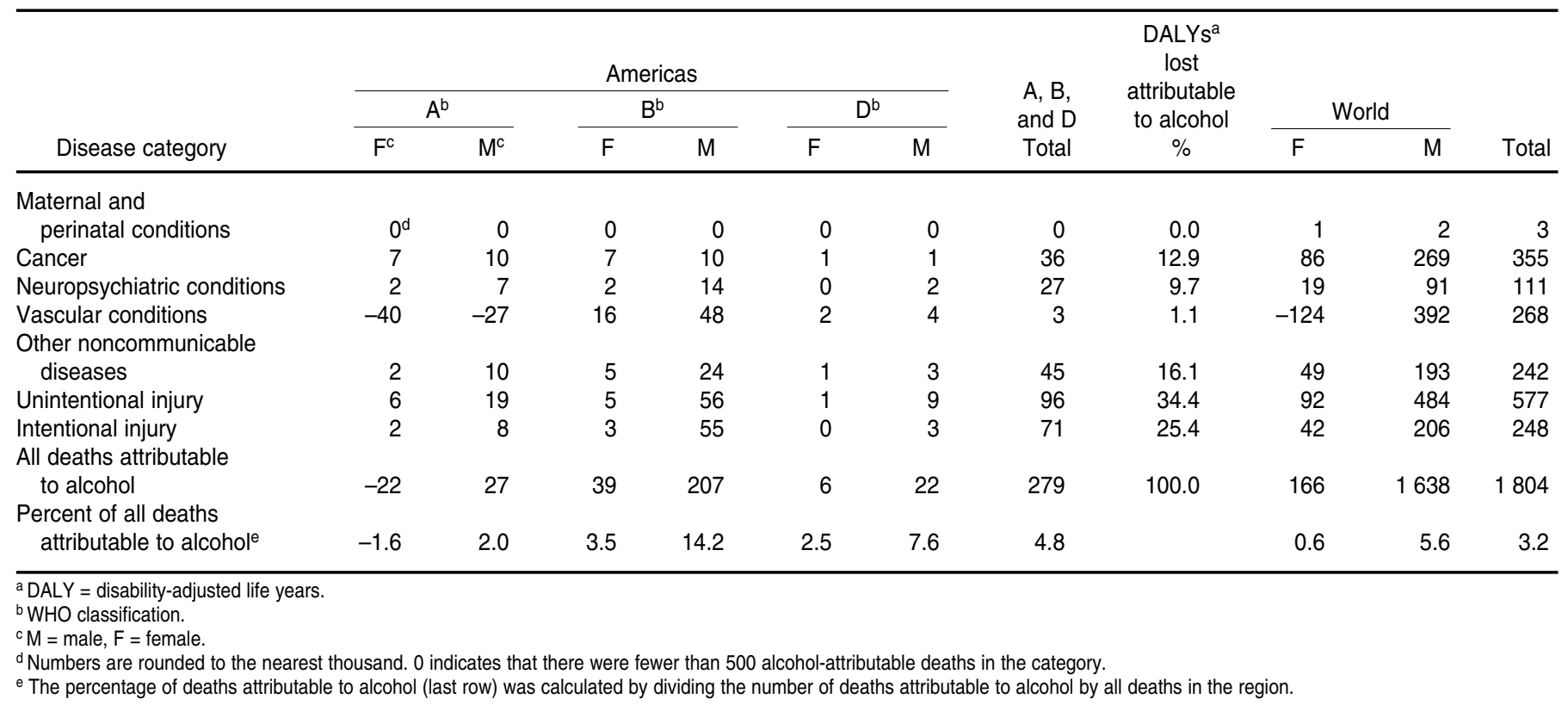

TABLE 5. Alcohol-related disease burden in disability-adjusted life years lost (DALYs) (thousands) in 2000 in the Americas and the world, by disease category and region (calculated from data in reference 2)

\begin{tabular}{|c|c|c|c|c|c|c|c|c|c|c|c|}
\hline \multirow{2}{*}{ Disease category } & \multicolumn{6}{|c|}{ Americas } & \multirow{2}{*}{$\begin{array}{l}\mathrm{A}, \mathrm{B}, \\
\text { and } \mathrm{D} \\
\text { Total }\end{array}$} & \multirow{2}{*}{$\begin{array}{c}\text { DALYs } \\
\text { lost } \\
\text { attributable } \\
\text { to alcohol } \\
\%\end{array}$} & & & \multirow{2}{*}{ Total } \\
\hline & \multicolumn{2}{|c|}{$A^{b}$} & \multicolumn{2}{|c|}{$\mathrm{B}^{\mathrm{b}}$} & \multicolumn{2}{|c|}{$D^{b}$} & & & \multicolumn{2}{|c|}{ World } & \\
\hline \multicolumn{12}{|l|}{ Maternal and } \\
\hline Cancer & 79 & 99 & 81 & 116 & 13 & 12 & 400 & 2.9 & 1021 & 3180 & 4201 \\
\hline \multicolumn{12}{|l|}{ Other noncommunicable } \\
\hline diseases & 25 & 165 & 101 & 531 & 20 & 55 & 897 & 6.5 & 860 & 3695 & 4555 \\
\hline Unintentional injury & 119 & 498 & 177 & 1815 & 29 & 268 & 2906 & 20.9 & 2487 & 14008 & 16495 \\
\hline Intentional injury & 53 & 222 & 118 & 1919 & 9 & 110 & 2431 & 17.5 & 1117 & 5945 & 7062 \\
\hline \multicolumn{12}{|l|}{ All DALYs lost attributable } \\
\hline to alcohol & 702 & 2925 & 1443 & 7854 & 170 & 789 & 13883 & 100.0 & 8926 & 49397 & 58323 \\
\hline
\end{tabular}

cohol-related disease burden $(82.1 \%)$ in age groups younger than 45 years.

The burden of disease and injury was greater in men than in women both in the Americas $(83.3 \%)$ and throughout the world $(84.7 \%)$.
Table 7 compares the impact of alcohol and other risk factors on the disease burden. In the Americas, alcohol was the risk factor that caused the greatest burden of disease, followed by smoking. Alcohol was also the risk factor that caused the greatest burden of disease in the two less developed regions, to be surpassed by smoking only in North America. Other risk factors differed across regions, with North America displaying a risk factor 
TABLE 6. Distribution of alcohol-related injury and disease burden in different age groups in the Americas in $\mathbf{2 0 0 0}$ and in the world (calculated from data in reference 2)

\begin{tabular}{lcccc}
\hline & \multicolumn{4}{c}{ Age (years) } \\
\cline { 2 - 5 } & $\begin{array}{c}0-14 \\
\%\end{array}$ & $\begin{array}{c}15-44 \\
\%\end{array}$ & $\begin{array}{c}45-69 \\
\%\end{array}$ & $\begin{array}{c}70 \text { and older } \\
\%\end{array}$ \\
\hline Americas & 4.7 & 77.4 & 17.0 & 0.9 \\
World & 4.3 & 68.1 & 25.3 & 2.3 \\
\hline
\end{tabular}

profile typical of developed countries. Lifestyle-related risk factors predominated, e.g., smoking, drinking and physical inactivity, and high body mass index, blood pressure and cholesterol levels. The least developed countries showed a considerable disease burden related to undernutrition (the second largest risk factor after alcohol) and environmental factors such as unsafe water and poor sanitation. Region B was somewhere in between, although its risk factor profile was more like that of North America.

\section{DISCUSSION}

Although alcohol is a major risk factor in several regions of the world, the Americas are unique in that alcohol surpasses smoking as the most important risk factor for burden of disease. The prevention of alcohol-related harm should therefore be a major public health priority in this region (28).
Before discussing prevention, however, the strengths and limitations of the estimates provided here should be examined. Clearly, the strength of the CRA is that the same method and the same database were used for mortality and morbidity statistics (6). As a result, the present comparison of risk factor estimates yields more information than the risk factor estimates of the 1990 GBD, which could not be compared across risk factors $(4,5,29)$.

Global and regional estimates of alcohol-related burden of disease from the CRA require a number of crucial assumptions. First, estimates of per capita consumption and unrecorded consumption for different countries are assumed not to contain substantial measurement error. Second, the distribution of consumption as deduced from surveys is assumed to be similar to the real distribution in the population. Third, alcohol-chronic disease relationships, as deduced from metaanalyses of cohort and case-control studies, are assumed to be stable across countries and regions.

There is evidence that per capita consumption can be estimated reliably, and per capita information is available for most countries (3). The reliability and coverage of information obtained from surveys are lower; however, since the overall and average volumes of per capita consumption were based on production or sales estimates, the figures for the volumes of alcohol consumed can be considered reliable. The most crucial element of our estimates is thus the stability of the relationships between alcohol and chronic disease.

There are indications that the relative risks for developing countries may not be the same as for developed countries; thus our estimates may be biased. However, newer epidemiological results in the Americas, based on direct assessments, appear to be similar to the results reported here. In addition, there are indications that earlier figures underestimated rather than overestimated the disease burden, due to the general shift in patterns of chronic disease and injury (3). Moreover, cultural elements in South America may have led to more harmful consequences than in other regions (30).

In any case, the disease burden is only part of the public health burden related to alcohol. In some countries the disease burden was actually less when compared to the social harm

TABLE 7. Leading risk factors for disease burden in $\mathbf{2 0 0 0}$ in different regions of the Americas ranked by percentage of disability-adjusted life years (DALYs) lost attributable to each factor (own calculations based on reference 2)

\begin{tabular}{lrlrl}
\hline \multicolumn{1}{c}{\begin{tabular}{c} 
Region D \\
\multicolumn{1}{c}{ (High childhood and adult mortality) }
\end{tabular}} & & \multicolumn{1}{c}{$\begin{array}{c}\text { Region B } \\
\text { (Low childhood and adult mortality) }\end{array}$} & \multicolumn{2}{c}{$\begin{array}{c}\text { Region A } \\
\text { (Very low childhood and adult mortality) }\end{array}$} \\
\hline Total DALYs (thousands) & 17052 & Total DALYs (thousands) & 80437 & Total DALYs (thousands) \\
Alcohol & 5.5 & Alcohol & 11.4 & Smoking \\
Underweight & 5.3 & Overweight & 4.2 & Alcohol \\
Unsafe sex & 4.8 & Blood pressure & 4.0 & Overweight \\
Unsafe water and sanitation & 4.3 & Smoking & 3.7 & Blood pressure \\
Overweight & 2.4 & Cholesterol & 2.3 & Cholesterol \\
Blood pressure & 2.2 & Unsafe sex & 2.1 & Low fruit and vegetable intake \\
Iron deficiency & 1.9 & Lead exposure & 2.1 & Physical inactivity \\
Indoor smoke & 1.9 & Low fruit and vegetable intake & 1.8 & Illicit drugs \\
Cholesterol & 1.1 & Unsafe water and sanitation & 1.6 & Unsafe sex \\
Low fruit and vegetable intake & 0.8 & Physical inactivity & 1.4 & Iron deficiency
\end{tabular}


caused by alcohol $(31,32)$. Some examples of alcohol-related social harm are family violence, aggression, or alcohol-related criminality (31). Thus, effective policies and interventions aimed at reducing the alcohol-related disease burden may have additional benefits by reducing social harm (32).

Measures to reduce the alcoholrelated public health burden are available (31-33). In view of the epidemiological situation in the Americas, four types of intervention should be given special attention:

- The primary focus should be injury prevention, including but not limited to interventions which reduce alcohol-related traffic accidents.

- The overall volume of consumption should be reduced. Different interventions are available to achieve this goal, with taxation being one of the most cost-effective measures $(32,34)$.

- Irregular heavy drinking should be reduced. Brief interventions have been shown to achieve this goal, but there are not many proven interventions to change long-term patterns of drinking.

- Given the large numbers of people with alcohol use disorders, evidencebased treatment interventions should be applied. Although treatment is not very cost-effective in reducing alcohol-related harm at the population level, it is effective at the individual level and should be part of an integrated, community-based health system.

Other elements which should be part of comprehensive alcohol policies include controls over the times when alcohol can be legally sold and its physical availability, density of outlets, minimum drinking age, effective deterrence, legislation to support enforcement and monitoring, regulations on advertising and the marketing of alcohol to young people, and regulating the market to reduce unrecorded alcohol consumption.

Overall, there is a need for national and community leaders to implement effective changes to reduce the burden of disease and social harm related to alcohol. It is up to the responsible policy makers to implement these measures. Without these policy changes, given the patterns of alcohol-related disease in the Americas, we can expect further increases in the alcohol-related public health burden, even if the current levels of consumption do not increase (3).

\section{REFERENCES}

1. Ezzati M, Lopez AD, Rodgers A, Vander Horn S, Murray CJL, and the Comparative Risk Assessment Collaborating Group. Selected major risk factors and global and regional burden of disease. Lancet 2002;360: 1347-60.

2. World Health Organization. World Health Report 2002: reducing risks, promoting healthy life. Geneva: WHO; 2002

3. Rehm J, Room R, Monteiro M, Gmel G, Graham K, Rehn N, et al. Alcohol use. In: Ezzati M, Lopez AD, Rodgers A, Murray CJL, eds. Comparative quantification of health risks: global and regional burden of disease due to selected major risk factors (Vol. 1). Geneva: WHO, 2004. Pp. 959-1108.

4. Murray CJL, Lopez A. Global mortality, disability, and the contribution of risk factors: global burden of disease study. Lancet 1997; 349:1436-42.

5. Murray CJL, Lopez A. The Global Burden of Disease: a comprehensive assessment of mortality and disability from diseases, injuries and risk factors in 1990 and projected to 2020. Boston: Harvard School of Public Health on behalf of the World Health Organization and the World Bank; 1996

6. Mathers $C D$, Stein $C$, Ma Fat D, Rao C, Inoue $\mathrm{M}$, Tomijima N, et al. Global burden of disease 2000: Version 2 methods and results. Geneva: WHO; 2002

7. Rehm J, Room R, Graham K, Monteiro M, Gmel G, Sempos CT. The relationship of average volume of alcohol consumption and patterns of drinking to burden of disease-an overview. Addiction 2003;98(10):1209-28.
8. Rehm J, Rehn N, Room R, Monteiro M, Gmel $G$, Jernigan D, et al. The global distribution of average volume of alcohol consumption and patterns of drinking. Eur Addict Res. 2003; 9(4):157-64.

9. World Health Organization. The World Health Report 2000-health systems: improving performance. Geneva: WHO; 2000.

10. English DR, Holman CDJ, Milne E, Winter MJ, Hulse GK, Codde G, et al. The quantification of drug-caused morbidity and mortality in Australia 1995. Canberra, Australia: Commonwealth Department of Human Services and Health; 1995.

11. Rehm J, Monteiro M, Room R, Gmel G, Jernigan D, Frick U, et al. Steps towards constructing a global comparative risk analysis for alcohol consumption: determining indicators and empirical weights for patterns of drinking, deciding about theoretical minimum, and dealing with different consequences. Eur Addict Res. 2001;7(3):138-47.

12. WHO Global Alcohol Database. Available at www.who.int/alcohol; http://www3.who. int/whosis/menu.cfm?path=whosis,alcohol \&language $=$ english. Accessed 26 July 2005.

13. Rehm J, Gmel G. Applying principles of comparative risk analysis to substance-abuse related burden. Eur Addict Res. 2001;7(3):95-7.

14. Gutjahr E, Gmel G, Rehm J. Relation between average alcohol consumption and disease: an overview. Eur Addict Res. 2001;7(3):117-27.

15. Corrao G, Rubbiati L, Bagnardi V, Zambon A, Poikolainen K. Alcohol and coronary heart disease: a meta-analysis. Addiction. 2000;95 (10):1505-23.
16. Ridolfo B, Stevenson C. The quantification of drug-caused mortality and morbidity in Australia 1998. Canberra, Australia: Australian Institute of Health and Welfare; 2001.

17. Gmel G, Rehm J, Frick U. Methodological approaches to conducting pooled cross-sectional time series analysis: the example of the association between all-cause mortality and per capita alcohol consumption for men in 15 European states. Eur Addict Res. 2001;7(3): 128-37.

18. Gmel G, Rehm J, Frick U. Trinkmuster, ProKopf-Konsum von Alkohol und koronare Mortalität. Sucht. 2003;49(2):95-104.

19. World Mental Health Survey Consortium. Prevalence, severity and unmet need for treatment of mental disorders in the World Health Organization Mental Health Surveys. JAMA. 2004:291:2581-90.

20. Andrade L, Walters EE, Gentil V, Laurenti R. Prevalence of ICD-10 mental disorders in a catchment area in the city of São Paulo, Brazil. Soc Psychiatry and Psychiatr Epidemiol. 2002; 37:316-25.

21. Kessler R, Aguilar-Gaxiola S, Andrade L, Bijl R, Borges G, Caravego-Anduaga JJ, et al. Cross-national comparisons of co-morbidities between substance use disorders and mental disorders: results from the International Consortium in Psychiatric Epidemiology. In: Bukoski WJ, Sloboda Z, eds. Handbook for drug abuse prevention theory, science, and practice. New York: Plenum; 2003. Pp. 447-72.

22. Vicente B, Kohn R, Rioseco P, Saldivia S, Baker C, Torres S. Population prevalence of psychiatric disorders in Chile: 6-month and 
1-month rates. Br J Psychiatry. 2004;184:299305.

23. Rehm J, Sempos CT, Trevisan M. Average volume of alcohol consumption, patterns of drinking and risk of coronary heart diseasea review. J Cardiovasc Risk. 2003;10:15-20.

24. Puddey IB, Rakic V, Dimmitt SB, Beilin LJ. Influence of drinking on cardiovascular disease and cardiovascular risk factors-a review. Addiction. 1999;94:649-63.

25. Sempos CT, Rehm J, Crespo C, Trevisan M. No protective effect of alcohol consumption on coronary heart disease (CHD) in African Americans: average volume of drinking over the life course and CHD morbidity and mortality in a U.S. national cohort. Cont Drug Probl. 2002;29:805-20.

26. McKee M, Britton A. The positive relationship between alcohol and heart disease in eastern Europe: potential physiological mechanisms. J R Soc Med. 1998;91:402-7.
27. Moares RS, Fuchs FD, Moreira LB, Wiehe M, Pereira GM, Fuchs SC. Risk factors for cardiovascular disease in a Brazilian populationbased study. Int J Cardiol. 2003;90:205-11.

28. Room R, Babor T, Rehm J. Alcohol and public health: a review. Lancet. 2005;365:519-30.

29. Murray CJL, Lopez A. On the comparable quantification of health risk: lessons from the Global Burden of Disease Study. Epidemiology. 1999;10:594-605.

30. Seale JP, Shellenberger S, Rodriguez C, Seale JD, Alvarado M. Alcohol use and cultural change in an indigenous population: a case study from Venezuela. Alcohol Alcohol. 2002; 37(6):603-8.

31. Room R, Graham K, Rehm J, Jernigan D, Monteiro M. Drinking and its burden in a global perspective: policy considerations and options. Eur Addict Res. 2003;9(4):165-75.

32. Babor T, Caetano R, Casswell S, Edwards G, Giesbrecht N, Graham K, et al. Alcohol: no ordinary commodity—a consumer's guide to Public Policy. Oxford: Oxford University Press; 2003.

33. Edwards G, Anderson P, Babor TF, Casswell S, Ferrence R, Giesbrecht N, et al. Alcohol policy and the public good. Oxford: Oxford University Press; 1994.

34. Chisholm D, Rehm J, van Ommeren M, Monteiro M. Reducing the global burden of hazardous alcohol use: a comparative costeffectiveness analysis. J Stud Alcohol. 2004;65: 782-93.

Manuscript received on 27 September 2004. Revised version accepted for publication on 13 May 2005.
RESUMEN

El consumo de alcohol y la carga de morbilidad en el continente americano: implicaciones para las políticas de control del consumo de alcohol
Objetivos. Describir las tendencias observadas en el consumo de alcohol en el continente americano, calcular la carga de morbilidad atribuible al alcohol en 2000 y examinar las consecuencias de políticas encaminadas a reducir la carga de enfermedad relacionada con el consumo de alcohol.

Métodos. Dos aspectos de la exposición al alcohol se abarcaron en este análisis de datos secundarios: el volumen promedio de alcohol consumido y los hábitos de consumo. Se establecieron dos parámetros de interés principales: la mortalidad (número de defunciones) y los años de vida perdidos, calculados en función de la presencia de discapacidad (DALY) (es decir, los años perdidos como resultado de una muerte temprana y de la presencia de discapacidad). Se hicieron cálculos separados en función del sexo, el grupo de edad y la región de la Organización Mundial de la Salud.

Resultados. A pesar de que se observan diferencias regionales, el consumo de alcohol en el continente americano fue, en promedio, más de $50 \%$ mayor que en el mundo en general. Se advirtió la tendencia a beber en exceso de manera errática. El consumo de alcohol explica una elevada fracción de la carga de morbilidad: 4,8\% de todas las muertes y $9,7 \%$ de todos los DALYs perdidos en 2000 se atribuyeron al consumo de alcohol, y la mayor parte de esta carga de morbilidad se observó en países que no pertenecen a América del Norte. Traumatismos intencionados y no intencionados fueron causa de 59,8\% de todas las defunciones relacionadas con el consumo de alcohol y de $38,4 \%$ de la carga de morbilidad correspondiente. De todos los factores de riesgo comparados en este trabajo, el alcohol aportó la mayor proporción del riesgo, seguido del tabaco.

Conclusiones. Se deben llevar a cabo intervenciones para reducir la elevada carga de morbilidad relacionada con el alcohol en el continente americano. Dada la estructura epidemiológica de esta carga, la prevención de traumatismos - no solo los provocados por accidentes de tránsito sino otros también-, así como la provisión de tratamientos adecuados, debe ser parte importante de todo plan general dirigido a reducir la carga sanitaria asociada con el consumo de alcohol.

Palabras clave Alcohol, factor de riesgo, morbilidad, mortalidad, años de vida perdidos, Américas. 